\title{
Farmers' preferred traits and perceived production constraints of bread wheat under drought-prone agro-ecologies of Ethiopia
}

Yared Semahegn ${ }^{1,2^{*}}$, Hussein Shimelis ${ }^{1}$, Mark Laing ${ }^{1}$ and Isack Mathew ${ }^{1}$

\begin{abstract}
Background: Bread wheat (Triticum aestivum L.) is a valuable commodity crop for local, regional and global markets. In Ethiopia, wheat ranks third after maize (Zea mays L.) and tef (Eragrostis tef Zucc.) in terms of total production, and fourth after maize, tef and sorghum (Sorghum bicolor $\mathrm{L}$.) in areas of cultivation. The major wheat-producing areas are mainly found in the mid-altitude (1900 to $2300 \mathrm{~m}$ above sea level) and high-altitude (2300 to $2700 \mathrm{~m}$ above sea level) regions of the country that are regarded as high-potential environments due to their high and reliable rainfall. However, wheat is widely adapted and grows in diverse environments. It is produced mainly under rainfed condition by small-scale farmers. The country is ranked first in wheat production in sub-Saharan Africa (SSA) followed by South Africa, Sudan and Kenya. However, the average productivity of the crop is 2.4 tons $\mathrm{ha}^{-1}$, which is lower than the global (3.4 tons ha ${ }^{-1}$ ) average, which is due to low adoption of new improved varieties. The objective of this study was to assess farmers' preferred traits of bread wheat variety, factors influencing their adoption for new improved variety and perceived production constraints of wheat under drought-prone agro-ecologies of Ethiopia.

Methodology: The study was conducted in selected districts of Arsi Zone in the Oromia Regional State of Ethiopia during 2018. A multistage random sampling was employed to arrive at household level. Data were collected based on primary and secondary sources. Relationships were examined through frequency, percentages and Chi-square values within and between districts for variables considered. Kendall's coefficient of concordance (W) analysis was used to identify the varietal attributes that are most preferred by the farmers. Binary logistic regression model was used to determine the factors influencing farmers' adoption of improved varieties. Rank Based Quotient (RBQ) was computed to identify the most important production constraints perceived by the farmers in the study areas.

Results: High grain yield was the most preferred trait as perceived by the farmers in the study areas followed by stress adaptation (drought and heat stress tolerance), disease resistance and early maturity. The binary logistic regression model showed socio-demographic characteristics, such as education had positive and significant $(p<0.01)$ effect on adoption of new improved bread wheat varieties. Gender and access to extension officers affected the adoption negatively and significantly $(p<0.05)$. Varietal attributes, such as early maturity $(p<0.01)$ and plant height $(p<0.05)$, had positive and significant effects on adoption of new improved varieties, while adaptation and baking quality had negative and significant $(p<0.05)$ influences on the acceptance of the new improved varieties. Moisture stress, disease (especially rust) and the high cost of fertilizers were, in order, first-, second- and third-ranked production constraints in the study areas.
\end{abstract}

*Correspondence: yaredsemahegnb@gmail.com

${ }^{2}$ Ethiopian Institute of Agricultural Research, Holetta Research Centre, P.O. Box 2003, Addis Ababa, Ethiopia

Full list of author information is available at the end of the article

c) The Author(s) 2021. This article is licensed under a Creative Commons Attribution 4.0 International License, which permits use, sharing, adaptation, distribution and reproduction in any medium or format, as long as you give appropriate credit to the original author(s) and the source, provide a link to the Creative Commons licence, and indicate if changes were made. The images or other third party material in this article are included in the article's Creative Commons licence, unless indicated otherwise in a credit line to the material. If material is not included in the article's Creative Commons licence and your intended use is not permitted by statutory regulation or exceeds the permitted use, you will need to obtain permission directly from the copyright holder. To view a copy of this licence, visit http://creativeco mmons.org/licenses/by/4.0/. The Creative Commons Public Domain Dedication waiver (http://creativecommons.org/publicdomain/ zero/1.0/) applies to the data made available in this article, unless otherwise stated in a credit line to the data. 
Conclusions: Farmers had different variety-specific trait preferences. Grain yield, rust resistance, adaptation to drought and heat stresses, and early maturity were the most farmer-preferred traits. Socio-demographic factors, such as gender, education level and access to extension officers, influenced variety adoption by the farmers. Early maturity, plant height, baking quality and stress adaptation were the major varietal characteristics contributing towards adoption of new improved bread wheat varieties. Drought stress, disease (especially rust) and the high cost of fertilizers were among the major constraints of wheat production identified by the farmers. This study can serve as a guide for future wheat breeding programmes incorporating farmer-preferred traits, including stress adaptation (drought and heat tolerance). This will enhance adoption of newly developed improved varieties and for sustainable production and food security of smallholder farmers in drought-prone areas. Future wheat improvement and extension programmes of the National Agricultural Research System (NARS) should involve marginal wheat-growing environments to boost adoption of new improved varieties and the production potential of the crop.

Keywords: Adoption, Bread wheat, Marginal environment, Ethiopia, Farmers' preferred traits, Farmers' perceptions, Production constraints of wheat

\section{Background}

Bread wheat (Triticum aestivum L.) is a valuable commodity crop for local, regional and global markets. In Ethiopia, wheat ranks third after maize (Zea mays L.) and tef (Eragrostis tef Zucc.) in terms of total production, and fourth after maize, tef and sorghum (Sorghum bicolor L.) in areas of cultivation [11]. The major wheatproducing areas are mainly found in the mid-altitude (1900 to $2300 \mathrm{~m}$ above sea level) and high-altitude (2300 to $2700 \mathrm{~m}$ above sea level) regions of the country that are regarded as high-potential environments due to their high and reliable rainfall. However, wheat is widely adapted and grows in diverse environments [35]. It is produced mainly under rainfed conditions by small-scale farmers. The country is ranked first in wheat production in sub-Saharan Africa (SSA), followed by South Africa, Sudan and Kenya [34]. Wheat provides about $15 \%$ of the national caloric intake [26]. Wheat production increased by $30.9 \%$ between $2011 / 12$ and $2015 / 16$ and reached 4.2 million tons in 2015/16, which was mainly due to an increased production area and improved productivity [11]. However, the average productivity of the crop is 2.4 tons $\mathrm{ha}^{-1}$, which is lower than the global (3.4 tons ha ${ }^{-1}$ ) average [15]. The demand for wheat is increasing due to population growth, the emergence of agro-processors, urbanization and increased household income [17, 31]. For instance, in 2013, 0.86 million tons of wheat was imported valued at USD 438.5 million [30].

Several improved varieties with superior qualities, which are adapted to various agro-ecological conditions, have been released by the national breeding programme. However, only few varieties have been adopted by farmers in marginal environments. Most varieties developed for high production environments were not as successful in marginal environments despite their high yield potential under optimal conditions [27]. Studies showed that a lack of systematic breeding process that incorporates farmers' preferred traits resulted in the poor performance and low adoption rates of new varieties by farmers under marginal conditions [5, 27, 34]. Several factors influence the adoption or non-adoption of improved varieties [10, 22, 32]. The factors that affect adoption of varieties by farmers in marginal conditions have been neglected in favour of household and farm characteristics of farmers in high-potential environments [40, 45, 46]. It is important to gain insight into farmers' preferences for varietal attributes, especially for farmers in marginal areas and the challenges pertinent to their production environments $[6,14,27]$.

Participatory rural appraisal (PRA) is a preliminary step of identifying farmers' needs and requirements and that of the marketplace. These will guide participatory plant breeding (PPB). Participatory plant breeding is an approach involving interaction between farmers and plant breeders in order to share knowledge and skills to develop suitable varieties [27]. This approach has developed as an alternative and complementary breeding approach to conventional breeding. The use of PPB has enabled breeders to develop crop varieties that are adapted to target environment and address the needs of the farmers in quality and quantity [38]. This can improve adoption rates of modern varieties among farmers, with less additional costs compared to conventional breeding [43].

Marginal environments are highly heterogeneous with numerous limiting factors for crop production, and would require stable varieties with unique characteristics for adaptation to improve their adoption rates by farmers in these environments. Under PPB, parental lines and segregating populations are selected in environments similar to farmers' conditions allowing breeders to appreciate the challenges faced by the farmers. This approach is value chain oriented and has been termed demandled breeding, which is a deviation from the conventional 
method of breeding according to breeders objectives. Engaging the farmers through a PPB to identify their challenges and needs will assist developing cultivars that meet farmers' expectations and demands [9, 18, 25]. This will enhance adoption rate of improved varieties [8, $21,39,41,44]$, which will, in turn, increase household income and improve food security $[4,31]$. The objective of this study was to assess farmers' preferred traits in a bread wheat variety, factors influencing their choices for adopting a new variety and production constraints of wheat that they perceive as important under droughtprone agro-ecologies of Ethiopia. This study seeks to understand how farmers perceive the existing wheat variety traits, what traits they prefer in a wheat variety, what factors influence their preferences and what productions factors are considered to be major constraints in their environment. This will provide useful information to breeders to develop varieties that are consistent with the needs of farmers, and it will also serve as a guide to policy making through addressing areas of intervention for effective promotion of domestic wheat production in Ethiopia.

\section{Materials and methods}

\section{Description of the study areas}

The study was conducted in Arsi Zone in the Oromia Regional State of Ethiopia during 2018 (Fig. 1). Oromia region accounts for more than $50 \%$ of the national wheat production area, while the Arsi Zone contributes above $25 \%$ of the national wheat production [11]. The zone is regarded as one of the wheat belts of the country [42]. There are about 24 districts in this zone with various agro-ecologies. For the purpose of this study, three wheat-producing districts, namely Sire, Dodota and Hetosa, were selected as these were prone to drought stress [29, 42, 47]. Production of field crops was the major source of income, and wheat, tef and barley (Hordeum vulgare) are the most commonly cultivated crops in these areas. Sire District lies between 1000 and $2500 \mathrm{~m}$ above sea level and at a latitude of $7^{\circ} 20^{\prime} 0^{\prime \prime}$ North and a longitude of $39^{\circ} 26^{\prime} 0^{\prime \prime}$ East. It has monomodal rainfall with a mean annual rainfall of $500 \mathrm{~mm}$ and average maximum and minimum monthly temperatures of $30{ }^{\circ} \mathrm{C}$ and $15{ }^{\circ} \mathrm{C}$, respectively. Dodota District is located within an altitude range from 1400 to $2500 \mathrm{~m}$ above sea level and latitude $8^{\circ}$ $14^{\prime} 60^{\prime \prime}$ North and $39^{\circ} 19^{\prime} 60^{\prime \prime}$ East. It has bimodal rainfall with a mean annual rainfall of $1000 \mathrm{~mm}$ and average maximum and minimum monthly temperatures of $25^{\circ} \mathrm{C}$ and $20^{\circ} \mathrm{C}$, respectively. Hetosa District is between 1500 and $4170 \mathrm{~m}$ above sea level and latitude $8^{\circ} 04^{\prime} 60^{\prime \prime}$ North and $39^{\circ} 14^{\prime} 60^{\prime \prime}$ East. It has monomodal rainfall with a mean annual rainfall of $1000 \mathrm{~mm}$ and average maximum and minimum monthly temperatures of $27^{\circ} \mathrm{C}$ and $14{ }^{\circ} \mathrm{C}$, respectively.

\section{Sampling and data collection procedure}

A multistage random sampling was employed to arrive at household level. The first stage of selection was based

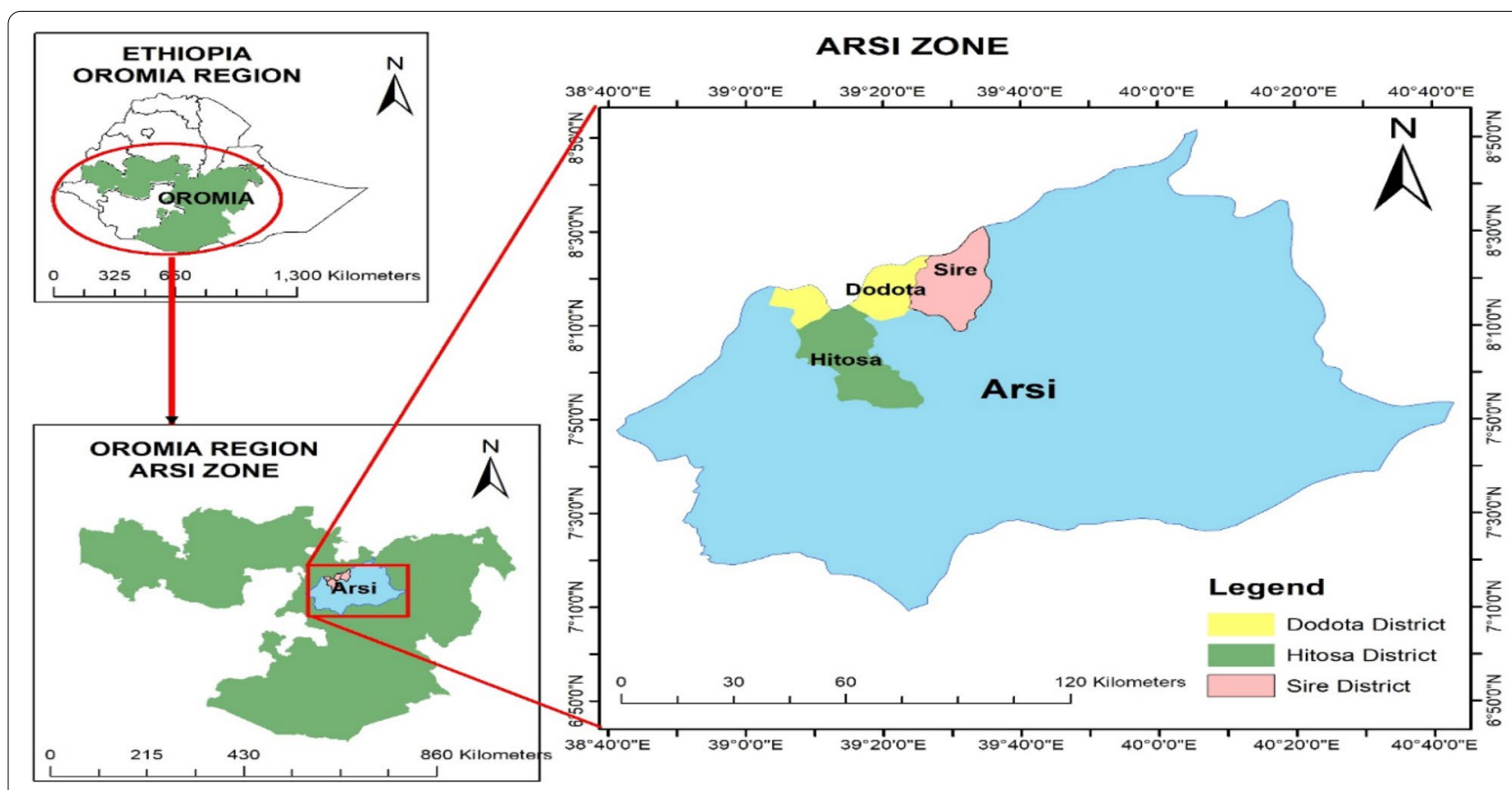

Fig. 1 Map of the study areas in Ethiopia 
on literature and central statistical data sources. The zone was identified as one of the wheat-producing regions [11]. In this region, wheat-producing districts which were prone to drought were selected with the help of Bureau of Agriculture and Natural Resources (BOANR) offices of the respective districts. Secondly, two villages (locally referred to as 'Kebeles') from each district, making a total of six villages, were selected. Only accessible villages practising wheat production under dryland system were selected. At the third stage of sampling, 23-31 households from each village were selected following a random sampling procedure, making a total of 170 household respondents (Table 1).

Data were collected based on primary and secondary sources. Primary data were collected through a formal survey in which household heads were interviewed using a semi-structured questionnaire. The responses from the sampled farmers were based on their previous farming experiences in the preceding 2017 cropping season. The questionnaire was pre-tested on five farmers and amended accordingly. Enumerators were trained to improve efficiency and accuracy in data collection and clarity in elaborating questions to respondents. Through the questionnaire, data were collected on demographic and socio-economic characteristics of the households, farmers' preferred traits of bread wheat varieties and perceived production constraints. Interviews were conducted using the local languages (Oromiffa and Amharic) translated with the help of local people and agricultural extension staff stationed in the respective areas. Secondary data were obtained on cropping system, cropping calendar and the sensitivity of drought in the farming community using a designed checklist, involving key informants comprising districts agricultural office leaders and agricultural extension officers, village agricultural extension officers and village leaders. In addition, personal observations were made by the research team

Table 1 Districts, villages and number of farmers sampled for this study

\begin{tabular}{llllc}
\hline Districts & Villages & \multicolumn{3}{c}{ Number of farmers } \\
\cline { 3 - 5 } & & Male & Female & Total \\
\hline \multirow{2}{*}{ Sire } & Koloba Bele & 31 & - & 31 \\
\multirow{2}{*}{ Dodota } & Ebseta Eduga & 19 & 4 & 23 \\
& Dodota Alem & 26 & 1 & 27 \\
\multirow{2}{*}{ Hetosa } & Amigna Dabesa & 24 & 7 & 31 \\
& Anole Salan & 25 & 5 & 30 \\
Total & Deyea Debeso & 22 & 6 & 28 \\
& & 147 & 23 & 170 \\
\hline
\end{tabular}

using a transect walk across the villages to visually appreciate the cropping system and weather condition of the areas. Quantitative data further describing the areas regarding altitude, geographic position, rainfall pattern, annual rainfall and temperature were obtained from the respective districts' Bureau of Agriculture and Natural Resources (BOANR) offices.

\section{Data analysis}

Statistical analyses, such as frequency, percentages, Chi-square, Kendall's coefficient of concordance (W), rank based quotient and binary logistic regression model, were employed using the Statistical Package for Social Sciences (SPSS) version 24 [33]. Relationships were examined through frequency, percentages and Chi-square values within and between districts for variables considered. To examine farmers' preferences for varietal traits, each farmer were asked what specific variety of bread wheat he/she cultivated in 2017 cropping season, and what was his/her perception for certain attributes of the variety. The specific attribute of the variety considered 'good' was assigned a number ' 1 ' and otherwise a '2', and Kendall's coefficient of concordance (W) analysis was used to identify the varietal attributes that are most preferred by the farmers [3]. Attributes that were regarded as neutral (neither good nor bad) were excluded from the analysis. To draw inferences on farmers' preferences, further analysis was conducted to identify key variables affecting farmer's decision with a dichotomous outcome $(Y)$ depending on socio-demographic characteristics and the specific perceived attributes of the improved wheat varieties. Farmer's decision refers to the use of new improved varieties (three new improved varieties were identified out of which a farmer who used at least one was considered as adopter (early adopter) represented by ' $Y=1$ ' otherwise non-adopter represented by ' $Y=0$ '. Sociodemographic factors, such as gender, age, education, family size, extension contact, farmers' associations and owned-land size, were expected to affect farmers' adoption of new improved varieties. Likewise, varietal attributes, such as grain yield, early maturity, tillering capacity, plant height, grain weight, disease resistance, adaptation (drought and heat stresses) and baking quality, were expected to affect farmers' choices of new improved varieties in the study areas. Data were tested using various models, but binary logistic regression model was found to be the best for the present study [6]. The model specified was as follows:

$$
P_{I}=E\left[Y=1 \mid X_{i-m}\right]=\frac{1}{1+e^{-\left(\beta_{0}+\sum_{i}^{m} \beta_{i} X_{i}\right)}} .
$$


To obtain an estimate of the odds ratio $\left(\frac{P_{I}}{1-P_{I}}\right)$,

$$
\operatorname{odds}\left(P_{I}\right)=\frac{P_{I}}{1-P_{I}}=\frac{1-e^{\left(\beta_{0}+\sum_{i}^{m} \beta_{i} X_{i}\right)}}{1-e^{-\left(\beta_{0}+\sum_{i}^{m} \beta_{i} X_{i}\right)}}=e^{\left(\beta_{0}+\sum_{i}^{m} \beta_{i} X_{i}\right)} .
$$

For each data point, logit I is represented by

$$
\operatorname{logit}\left(P_{I}\right)=E\left[Y=1 \mid X_{i-m}\right]=\ln \left(\frac{P_{I}}{1-P_{I}}\right)=\beta_{0}+\sum_{i}^{m} \beta_{i} X_{i}+\varepsilon,
$$

where $E(Y=1 \mid X)$ represents the expected value of $Y$ equals to 1 , given the value $X ; P_{I}$ the probability of the $I$ th farmer choosing to use the improved variety(ies) ranges from 0 to $1 ; \beta_{0}$ constant; $\beta_{i}$ the parameter estimates for the independent variables; $X_{i}$ the set of independent variables $(i=1,2, \ldots, m)$; $e$ base of natural logarithms and $\varepsilon$ an error term.

For production constraints, 12 constrains were predefined and farmers were asked to state if the severity of each was high, medium or low based on their perceptions, designated by ranking as first, second or third, respectively. The responses were analysed using Rank Based Quotient (RBQ) to identify the most important production constraints as perceived by the farmers in the study areas.

$\mathrm{RBQ}$ was calculated by using the following formula:

$$
\mathrm{RBQ}=\sum f_{i}(n+1-i) \times 100 / N \times n,
$$

where firepresents the frequency of respondents perceiving a particular constraint under ith rank; $N$ the total number of respondents; $n$ thenumber of constraints identified and $i$ the rank of the perceived constraint.

\section{Results}

\section{Demographic characteristics of the households}

Districts significantly varied regarding demographic characteristics, such as age $\left(X^{2}=22.615 ; p=0.004\right)$, education level $\left(X^{2}=23.305 ; p=0.010\right)$ and family size $\left(X^{2}=20.115 ; p=0.003\right)$ (Table 2). In Sire District, 92.6\% of the households were male headed. Similarly, 86.2 and

\begin{tabular}{|c|c|c|c|c|c|c|}
\hline \multirow[t]{2}{*}{ Descriptions } & \multicolumn{3}{|l|}{ Districts } & \multirow[t]{2}{*}{ Degrees of freedom } & \multirow[t]{2}{*}{$X^{2}$-value } & \multirow[t]{2}{*}{$p$-value } \\
\hline & Sire & Dodota & Hetosa & & & \\
\hline \multicolumn{7}{|l|}{ Sex } \\
\hline Male & $50(92.6)$ & $50(86.2)$ & $47(81)$ & 2 & 3.198 & 0.202 \\
\hline Female & $4(7.4)$ & $8(13.8)$ & $11(19)$ & & & \\
\hline \multicolumn{7}{|l|}{ Age (years) } \\
\hline $18-25$ & $1(1.9)$ & $1(1.7)$ & $3(5.2)$ & 8 & 22.615 & 0.004 \\
\hline $26-35$ & $21(38.9)$ & $12(20.7)$ & $4(6.9)$ & & & \\
\hline $36-45$ & $16(29.6)$ & $22(37.9)$ & $20(34.5)$ & & & \\
\hline $46-60$ & $12(22.2)$ & $19(32.8)$ & $19(32.8)$ & & & \\
\hline$>60$ & $4(7.4)$ & $4(6.9)$ & $12(20.7)$ & & & \\
\hline \multicolumn{7}{|l|}{ Educational level } \\
\hline Illiterate & $9(16.7)$ & $5(8.6)$ & $14(24.1)$ & 10 & 23.305 & 0.010 \\
\hline Read and write & $2(3.7)$ & $2(3.4)$ & $8(13.8)$ & & & \\
\hline Elementary (Grade 1-4) & $18(33.3)$ & $9(15.5)$ & $8(13.8)$ & & & \\
\hline Elementary (Grade 5-8) & $15(27.8)$ & $24(41.4)$ & $19(32.8)$ & & & \\
\hline Secondary (Grade 9-10) & $10(18.5)$ & $15(25.9)$ & $7(12.1)$ & & & \\
\hline Higher education & - & $3(5.2)$ & $2(3.4)$ & & & \\
\hline \multicolumn{7}{|c|}{ Family size (number per household) } \\
\hline$<3$ & $1(1.8)$ & $1(1.7)$ & $2(3.4)$ & 6 & 20.115 & 0.003 \\
\hline $3-5$ & $29(53.7)$ & $26(44.8)$ & $14(24.1)$ & & & \\
\hline $6-8$ & $21(38.9)$ & $25(43.1)$ & $24(41.4)$ & & & \\
\hline$>8$ & $3(5.6)$ & $6(10.3)$ & $18(31.0)$ & & & \\
\hline
\end{tabular}
$81 \%$ of the households in Dodota and Hetosa districts,

Table 2 Demographic characteristics of the households in the study areas

Source: Farm household survey, 2018

(-) indicates no response. Values outside and inside the bracket indicate the frequency and proportion in percent, respectively 
respectively, were male headed. The ages of the respondent farmers varied from 18 to over 60 years. More than $34 \%$ of the interviewed farmers in the Dodota and Hetosa districts were between 36 and 45 years of age. However, in Sire District, farmers in the 26 to 35 years' category accounted for the largest proportion (38.9\%), while those between 36 and 45 years of age made up $29.6 \%$ of the respondents. The Hetosa District had significantly more farmers in advanced age (above 60 years) accounting for $20.7 \%$, compared to less than $8 \%$ for the Sire and Dodota regions. There were more youths in Hetosa (5.2\%) than in Sire (1.9\%) and Dodota (1.7\%).

The majority $(76.4 \%)$ of the respondents had attained at least elementary level (Grades 1-4) education and could read and write proficiently, while the remainder was either illiterate or could only read and write with a limited comprehension. At the individual district level, the highest proportion (33.3\%) of the respondent farmers in Sire had attended elementary school (Grades 1 to 4). In comparison, there were only 15.5 and $13.8 \%$ in Dodota and Hetosa, respectively, who attained elementary education. However, more respondents in Dodota (41.4\%) and Hetosa (32.8\%) had attained Grades 5-8 education than those in Sire District (27.8\%). There were more respondents who attained secondary (25.9\%) and higher education $(5.2 \%)$ in Dodota than in Hetosa and Sire districts. None of the respondents in Sire had more than secondary education.

There were significant differences between Hetosa and the other two districts in terms of family size of more than eight family members. $31 \%$ of the respondents in Hetosa District had a family of more than eight members, compared to $10.3 \%$ and $5.6 \%$ recorded in Dodota and Sire districts, in that order. There were also significant differences among the districts regarding the smaller family units. Family units with 3 to 5 members accounted for $53.7 \%$ of the respondents in Sire compared to $44.8 \%$ in Dodota and $24.1 \%$ in Hetosa districts. The extent of medium-sized families and families with three or less members were not significantly different among the districts. About $40 \%$ of the households in all the districts had a family size of between six and eight members, while less than $4 \%$ of all respondents had a family size of three or below.

\section{Socio-economic characteristics of the households}

The farms size owned by the respondents ranged between less than 1 ha to more than 3 ha (Table 3 ). The sizes of the farms owned varied significantly across the districts $\left(X^{2}=18.905 ; p=0.001\right)$. The Sire District was dominated by farmers who owned less than 1 ha $(50 \%)$, while 56.9 and $65.5 \%$ of the farmers in Dodota and Hetosa, respectively, owned between 1 and 3 ha of land. In Dodota, there was a significantly higher proportion (20.7\%) of farmers who owned more than 3 ha of land compared to $3.4 \%$ in Hetosa and 5.6\% in Sire. The sources of improved seed were also significantly different among the districts $\left(X^{2}=34.51 ; p=0.001\right)$. Most of the respondent farmers in Sire (46.3\%) and Dodota (44.8\%) districts accessed improved seed from their respective BOANR offices, while farmers in Hetosa (34.5\%) predominantly sourced seed from farmers' cooperatives. The farmers in all the different surveyed districts obtained information through different channels $\left(X^{2}=13.784 ; p=0.032\right)$ (Table 3). Agriculture extension services were the major source of information for the farmers in all the districts. More than $53 \%$ of all respondents in Sire confirmed that agricultural extension officers were their primary source of information, while the proportions were 67.2 and $72.4 \%$ in Hetosa and Dodota, respectively. The majority (more than $51 \%$ ) of the respondents in each district confirmed membership to one or multiple farmers' organizations. There was also a considerable proportion (up to 48\%) who were not members of any farmers' organizations. Most of the farmers (57.4\% in Sire, 56.9\% in Dodota and $69 \%$ in Hetosa) were members of a farmers' organization for less than five years.

\section{Farmers' preferences of bread wheat varieties for production, marketing and consumption}

Bread wheat varieties, such as Ogolcho, Kubsa, Kekeba, Batu, Hidase, Pavon 76, Kingbird, Hawi and Bafane, were widely cultivated in the study areas (Table 4). Ogolcho, Kekeba and Hidase were recently released new improved varieties, whereas the other could be regarded as traditional varieties, which were released about two decades ago. Batu and Kekeba were the most grown varieties in Sire, grown by 44.4 and $31.5 \%$ of the respondents, respectively. In Dodota, variety Ogolcho was grown by $56.9 \%$ of the respondents, three times more than the variety, Batu with $19 \%$. The Kubsa variety was grown by $46.6 \%$ of the respondents in Hetosa, while the varieties Ogolcho and Hidase were also grown with respective adoption rates of 29.3 and $25.9 \%$.

To gain an understanding of farmers' preferences for various bread wheat attributes, they were asked their perceptions on some traits of varieties, and ranked accordingly as presented in Table 5 . High grain yield was the most preferred trait as perceived by the farmers in the study areas, while adaptation to drought and heat stresses and disease resistance were ranked a joint second, and early maturity was ranked third. However, farmers in Sire ranked early maturity and adaptation as the second and third most preferred traits, in that order after grain yield. In Dodota, disease resistance and adaptation were ranked second and third, respectively, with grain yield being the 
Table 3 Socio-economic characteristics of the households in the study areas

\begin{tabular}{|c|c|c|c|c|c|c|}
\hline \multirow[t]{2}{*}{ Descriptions } & \multicolumn{3}{|l|}{ Districts } & \multirow{2}{*}{$\begin{array}{l}\text { Degrees } \\
\text { of freedom }\end{array}$} & \multirow[t]{2}{*}{$X^{2}$-value } & \multirow[t]{2}{*}{$p$-value } \\
\hline & Sire & Dodota & Hetosa & & & \\
\hline \multicolumn{7}{|l|}{ Farm size owned } \\
\hline$<1$ ha & $27(50.0)$ & $13(22.4)$ & $18(31.0)$ & 4 & 18.905 & 0.001 \\
\hline $1-3$ ha & $24(44.4)$ & $33(56.9)$ & $38(65.5)$ & & & \\
\hline$>3$ ha & $3(5.6)$ & $12(20.7)$ & $2(3.4)$ & & & \\
\hline \multicolumn{7}{|l|}{ Improved seed source } \\
\hline Farmers' cooperative & $10(18.5)$ & $7(12.1)$ & $20(34.5)$ & 12 & 34.51 & 0.001 \\
\hline Research centre & $3(5.6)$ & $3(5.2)$ & $3(5.2)$ & & & \\
\hline Seed enterprise & $3(5.6)$ & $2(3.4)$ & $3(5.2)$ & & & \\
\hline Farm saved & $1(1.9)$ & $1(1.7)$ & $9(15.5)$ & & & \\
\hline Neighbouring farmers & $9(16.7)$ & $18(31.0)$ & $14(24.1)$ & & & \\
\hline NGO & $3(5.6)$ & $1(1.7)$ & - & & & \\
\hline BOANR & $25(46.3)$ & $26(44.8)$ & $9(15.5)$ & & & \\
\hline \multicolumn{7}{|l|}{ Source of extension information } \\
\hline Agricultural Extension Staff (DAs) & $29(53.7)$ & $42(72.4)$ & $39(67.2)$ & 6 & 13.784 & 0.032 \\
\hline Radio & $22(40.7)$ & $13(22.4)$ & $13(22.4)$ & & & \\
\hline Television & $2(3.7)$ & - & - & & & \\
\hline Other & $1(1.9)$ & $3(5.2)$ & $6(10.3)$ & & & \\
\hline \multicolumn{7}{|l|}{ Membership to farmers' organization } \\
\hline Yes & $32(59.3)$ & $30(51.7)$ & $33(56.9)$ & 2 & 0.681 & 0.712 \\
\hline No & $22(40.7)$ & $28(48.3)$ & $25(43.1)$ & & & \\
\hline \multicolumn{7}{|c|}{ Years of membership to farmers' organization } \\
\hline$<5$ & $31(57.4)$ & $33(56.9)$ & $40(69.0)$ & 4 & 2.556 & 0.635 \\
\hline $5-10$ & $11(20.4)$ & $11(19.0)$ & $7(12.1)$ & & & \\
\hline$>10$ & $12(22.2)$ & $14(24.1)$ & $11(19.0)$ & & & \\
\hline
\end{tabular}

Source: Farm household survey, 2018

(-) indicates no response. Values outside and inside the bracket indicate the frequency and proportion in percentage, respectively

Table 4 Wheat varieties grown by the farmers in the study areas

\begin{tabular}{|c|c|c|c|c|}
\hline \multirow[t]{2}{*}{ Varieties $^{a}$} & \multirow{2}{*}{$\begin{array}{l}\text { Year of release/ } \\
\text { registration }\end{array}$} & \multicolumn{3}{|l|}{ Districts } \\
\hline & & Sire & Dodota & Hetosa \\
\hline \multicolumn{5}{|c|}{ New improved varieties } \\
\hline Ogolcho & 2012 & $9(16.7)$ & $33(56.9)$ & $17(29.3)$ \\
\hline Hidase & 2012 & - & - & $15(25.9)$ \\
\hline Kekeba & 2010 & $17(31.5)$ & $1(1.7)$ & $1(1.7)$ \\
\hline \multicolumn{5}{|c|}{ Old improved varieties } \\
\hline Kingbird & 2007 & - & $1(1.7)$ & - \\
\hline Hawi & 2000 & - & $1(1.7)$ & $1(1.7)$ \\
\hline Kubsa & 1995 & $3(5.6)$ & $5(8.6)$ & $27(46.6)$ \\
\hline Batu & 1984 & $24(44.4)$ & $11(19.0)$ & - \\
\hline Pavon 76 & 1982 & $2(3.7)$ & $5(8.6)$ & - \\
\hline Bafane & - & - & $2(3.5)$ & - \\
\hline
\end{tabular}

Source: Farm household survey, 2018

a Some farmers grow more than one variety, which makes the proportion above 100 percent. ${ }^{\text {b }}$ Released/registered by Kulumsa Agricultural Research Centre. (-) indicates not available/no response. Values outside and inside the bracket indicate the frequency and proportion in percentage, respectively first. In Hetosa, baking quality and disease resistance were ranked a joint second, and stress adaptation was ranked third, while grain yield was ranked first. Across the study areas, baking quality, tall plant height and tillering capacity were considered to be the fourth, fifth and sixth ranked preferred traits, respectively. The Kendall's W result indicated that only $16.5 \%$ of the respondent farmers agreed on the outcome of the ranking with probability level of $<1 \%$ across the study areas. However, the highest agreement among the farmers was observed in Dodota $(25.0 \%)$ followed by Hetosa $(18.1 \%)$ and Sire (16.0\%) (Table 5).

\section{Factors influencing farmers' varietal preferences}

Descriptions of the variables used in the binary logistic regression model and the results of the pooled regression coefficients for all districts are summarized in Tables 6 and 7. Before the variables were entered into the model, multi-collinearity analysis was done. No significant correlation was found between the variables. This was inferred from the Variance Inflation Factor (VIF) 
Table 5 Ranking of some bread wheat variety traits as perceived by the farmers in the study areas

\begin{tabular}{|c|c|c|c|c|c|c|c|c|}
\hline \multirow[t]{3}{*}{ Traits } & \multicolumn{8}{|l|}{ Districts } \\
\hline & \multicolumn{2}{|l|}{ Sire } & \multicolumn{2}{|l|}{ Dodota } & \multicolumn{2}{|l|}{ Hetosa } & \multicolumn{2}{|l|}{ Across } \\
\hline & Mean rank & Rank & Mean rank & Rank & Mean rank & Rank & Mean rank & Rank \\
\hline High yielding & 3.80 & 1 & 2.84 & 1 & 3.26 & 1 & 3.29 & 1 \\
\hline Early maturing & 3.96 & 2 & 5.32 & 5 & 5.08 & 5 & 4.80 & 3 \\
\hline Tillering capacity & 5.44 & 6 & 5.47 & 7 & 5.55 & 7 & 5.49 & 6 \\
\hline Plant height (tall) & 5.68 & 8 & 5.40 & 6 & 5.00 & 4 & 5.36 & 5 \\
\hline Grain weight & 5.35 & 5 & 5.86 & 8 & 5.71 & 8 & 5.65 & 7 \\
\hline Resistance to disease (rust) & 5.03 & 4 & 4.16 & 2 & 5.16 & 6 & 4.77 & 2 \\
\hline Resistance to shattering & 5.60 & 7 & 6.02 & 9 & 5.79 & 9 & 5.81 & 8 \\
\hline Baking quality & 5.44 & 6 & 5.24 & 4 & 4.53 & 2 & 5.06 & 4 \\
\hline Adaptation (drought, heat stresses) & 4.70 & 3 & 4.70 & 3 & 4.92 & 3 & 4.77 & 2 \\
\hline Kendall's W (significance) & $0.160(0.000)$ & & $0.250(0.000)$ & & $0.181(0.000)$ & & $0.165(0.000)$ & \\
\hline
\end{tabular}

Source: Farm household survey, 2018

Table 6 Description of variables used in the binary logistic regression model $(n=170)$

\begin{tabular}{|c|c|c|}
\hline Variables & Expected sign & References \\
\hline \multicolumn{3}{|l|}{ Socio-demographic characteristics } \\
\hline Gender $($ male $=1)$ & \pm & {$[6,10,16,23,24,31,32,45]$} \\
\hline Age (productive age between 18 and 60 years; yes $=1$ ) & \pm & \\
\hline Education (at least basic $=1$ ) & + & \\
\hline Household size (continuous) & + & \\
\hline Extension contact (yes $=1$ ) & + & \\
\hline Member to farmers associations (yes $=1$ ) & + & \\
\hline Own land size (continuous) & + & \\
\hline \multicolumn{3}{|l|}{ Varietal attributes } \\
\hline High yielding (yes = 1) & + & {$[3,5,14,22,24]$} \\
\hline Early maturing (yes $=1$ ) & + & \\
\hline Tillering ability (good =1) & + & \\
\hline Plant height (tall) (yes $=1$ ) & + & \\
\hline Grain weight $($ good $=1)$ & + & \\
\hline Resistance to disease (rust) (yes $=1$ ) & + & \\
\hline Resistance to shattering (yes $=1$ ) & + & \\
\hline Baking quality (good $=1$ ) & + & \\
\hline Adaptation (drought and heat stresses) (good =1) & + & \\
\hline
\end{tabular}

+ , positive impact; -, negative impact

estimates which had values less than 2 (data not shown). Test statistics indicated that the model adequately fitted the data (Table 7). The binary logistic regression model showed that the level of education had positive and significant $(p<0.01)$ effect on adoption of new improved bread wheat varieties, while gender and contact with the extension officers affected the adoption negatively and significantly $(p<0.05)$. A unit increase in level of education would increase adoption of improved varieties by a factor of 5.56, whereas gender and a lack of extension contact reduced their adoption by factors of 0.21 and 0.37 , in that order. Varietal attributes, such as early maturity $(p<0.01)$ and plant height $(p<0.05)$, had positive and significant effects on the adoption of new improved varieties, while adaptation and baking quality had negative and significant $(p<0.05)$ influences on the acceptance of the new improved varieties. A unit increase in early maturity and plant height would increase adoption of improved varieties by factor of 11.61 and 4.48, in that order. Conversely, a unit increase in baking quality and 
Table 7 Binary logistic regression estimates of the factors influencing farmers' varietal preferences

\begin{tabular}{|c|c|c|c|c|c|}
\hline Variables & Coefficients & Standard error & Degree of freedom & $p$-value & Odds ratio \\
\hline \multicolumn{6}{|l|}{ Socio-demographic characteristics } \\
\hline Gender & -1.563 & 0.688 & 1 & 0.023 & 0.210 \\
\hline Age & -0.629 & 0.713 & 1 & 0.377 & 0.533 \\
\hline Education & 1.716 & 0.588 & 1 & 0.004 & 5.562 \\
\hline Household size & -0.058 & 0.085 & 1 & 0.494 & 0.944 \\
\hline Extension contact & -1.004 & 0.436 & 1 & 0.021 & 0.367 \\
\hline Farmers associations & -0.358 & 0.412 & 1 & 0.385 & 0.699 \\
\hline Own land size & -0.070 & 0.183 & 1 & 0.702 & 0.932 \\
\hline \multicolumn{6}{|l|}{ Varietal attributes } \\
\hline High yielding & 0.519 & 0.408 & 1 & 0.203 & 1.680 \\
\hline Early maturing & 2.452 & 0.602 & 1 & 0.000 & 11.612 \\
\hline Tillering ability & -0.699 & 0.713 & 1 & 0.327 & 0.497 \\
\hline Plant height & 1.500 & 0.708 & 1 & 0.034 & 4.480 \\
\hline Grain weight & -0.621 & 0.769 & 1 & 0.419 & 0.537 \\
\hline Resistance to disease (rust) & -0.377 & 0.462 & 1 & 0.414 & 0.686 \\
\hline Resistance to shattering & -2.100 & 1.398 & 1 & 0.133 & 0.122 \\
\hline Baking quality & -1.296 & 0.528 & 1 & 0.014 & 0.274 \\
\hline Adaptation (drought, heat stresses) & -1.304 & 0.515 & 1 & 0.011 & 0.271 \\
\hline Constant & 2.104 & 1.169 & 1 & 0.072 & 8.202 \\
\hline \multicolumn{6}{|l|}{ Statistics } \\
\hline \multicolumn{6}{|l|}{ Omnibus tests } \\
\hline Chi-square & 61.03 & & & & \\
\hline$p$-value & 0.000 & & & & \\
\hline \multicolumn{6}{|l|}{ Hosmer and Lemeshow test } \\
\hline Chi-square & 6.801 & & & & \\
\hline$p$-value & 0.558 & & & & \\
\hline-2 log likelihood & 172.28 & & & & \\
\hline Cox and Snell R Square & 0.302 & & & & \\
\hline Nagelkerke R Square & 0.404 & & & & \\
\hline
\end{tabular}

Source: Farm household survey, 2018; Dependent variable indicates growing new improved bread wheat variety $(1=$ yes, $0=$ no)

adaptation will reduce adoption of improved varieties by a factor of 0.27 .

\section{Farmers' perceptions of the primary constraints to bread wheat production}

The production constraints of bread wheat perceived by the farmers in the study areas are presented in Table 8. The RBQ result indicated that moisture stress, disease (especially rust) and the high cost of fertilizers were the first-, second- and third-ranked production constraints, in that order. Other perceived constraints, such as heat stress, insect pests, soil erosion and seed shortage, were also considered to be important in the study areas.

\section{Discussion}

Characteristics of the farmers in the study areas

Household characteristics affect the decision-making of smallholder farmers [36]. The majority of respondent farmers $(86.5 \%)$ were male headed, which also meant that land was primarily owned by males, in line with traditional land holding tenure practices common in wheat farming in Ethiopia [28]. The majority of respondents had at least basic education (read and write). Likewise, most of the households were in the range of productive age (18-60 years). The average household had 6 family members of the age group between 26 and 45 years, which suggests that there was adequate family labour for wheat production. Household family size determines the availability of labour that affects the use of improved varieties and other production practices $[12,16]$. Above $50 \%$ of the respondents were members of a farmers' organization, which could help farmers to access agricultural information and improved technologies [12, 20, 23]. In this study, the main source of extension information for the majority of the sample households (65\%) was found to be agricultural extension staff, which was in agreement with other 
Table 8 Farmers' perceived constraints to bread wheat production in the study areas

\begin{tabular}{|c|c|c|c|c|c|c|}
\hline \multirow[t]{2}{*}{ Constraints } & \multirow[t]{2}{*}{ No of farmers } & \multicolumn{3}{|c|}{ Ranking } & \multirow[t]{2}{*}{ RBQ } & \multirow[t]{2}{*}{ Rank } \\
\hline & & 1 & 2 & 3 & & \\
\hline Low soil fertility & 170 & 38.2 & 56.5 & 5.3 & 55.5 & 9 \\
\hline Low yield & 170 & 48.8 & 51.2 & - & 56.3 & 8 \\
\hline Seed shortage & 170 & 54.1 & 44.1 & 1.8 & 56.5 & 7 \\
\hline Low price & 170 & 24.7 & 50.6 & 24.7 & 53.9 & 12 \\
\hline High cost of fertilizer & 170 & 72.9 & 26.5 & 0.6 & 57.5 & 3 \\
\hline Moisture stress & 170 & 92.9 & 7.1 & - & 58.5 & 1 \\
\hline Heat stress & 170 & 70.6 & 29.4 & - & 57.4 & 4 \\
\hline Insect pests & 170 & 68.8 & 25.3 & 5.9 & 57.0 & 5 \\
\hline Disease (especially rust) & 170 & 85.3 & 14.1 & 0.6 & 58.1 & 2 \\
\hline Weeds & 170 & 31.2 & 41.2 & 27.6 & 54.1 & 11 \\
\hline Lack of access to credit & 170 & 40.6 & 32.4 & 27.1 & 54.6 & 10 \\
\hline Land degradation/soil erosion & 170 & 64.7 & 31.8 & 3.5 & 56.9 & 6 \\
\hline
\end{tabular}

Source: Farm household survey, 2018; RBQ indicates Rank Based Quotient

studies that found that extension service was the major source of information for most smallholder farmers [7, 28]. On average, $35.3 \%$ of the sample households sourced their improved seed from BOANR, indicating the important role of government agencies in provision of agricultural inputs. $24.1 \%$ and $21.8 \%$ of the households obtained their improved seed from neighbouring farmers and farmers' cooperatives, respectively, which is an indication of the augmenting roles that farmers can play in organizing themselves to avoid over dependence on government. Similarly, Zegeye et al. [46] found that Bureau of Agriculture was the most important initial source of seed of improved wheat varieties. Doss et al. [12] reported that purchase, other farmers, extension and recycling own seed as the four main sources of seed for Ethiopian farmer. Farmers owned farm size ranging between 0.0 and 6.0 ha with a mean of 1.9 ha, which confirms that wheat production in the study areas was practised on a smallholder scale.

\section{Farmers' preferences of bread wheat varieties for production, marketing and consumption}

Farmers' varietal preferences vary from season to season, from location to location and from farmer to farmer [27], and their perceptions of varietal attributes affect their adoption of improved varieties [22]. Less than 50\% of the farmers concurred in their preferences for varietal traits in each district and across the study areas, calling for efficient breeding aimed at developing cultivars that integrate farmers' preferred traits [27]. Grain yield was the most preferred trait of bread wheat varieties across the study areas followed by disease resistance, adaptation and early maturity. Similarly, Abakemal et al. [1] reported that grain yield was the most preferred trait in maize in the Highlands of Ethiopia. The farmers mentioned that they would prefer varieties with disease resistance because they do not afford chemical pesticides, and have limited information on the suitable chemicals. Smallholder farmers lack options for disease control due to a lack of knowledge, and access to fungicides, among other factors [24]. As the study areas were characterized as lowlands that commonly experience moisture stress during the beginning and post flowering stages of the crop (data not shown), farmers preferred an early maturing and well adapted or drought-tolerant variety. Tall varieties with a high tillering capacity and good baking quality were also preferred by the farmers. Baking quality is an important trait because it increases consumers' demand and market value. However, the baking quality of the new improved varieties was recognized as being inferior to that of the traditional varieties. Preference for tall height is usually driven by the need for straw for use as livestock feed and other purposes, such as thatching. However, the tall varieties should have resistance to lodging that could otherwise have adverse effect on yield and result in low adoption [24].

\section{Factors influencing farmers' varietal preferences}

Various factors, such as the demographic, socio-economic and variety-specific attributes, influence farmers' preferences for improved varieties [21, 24]. Gender, level of education and extension contact were the major factors that influenced adoption of new improved varieties in the study areas. Gender had negative and significant effect on adoption of new improved varieties. Solomon et al. [32] reported that the gender of 
the household head had a positive effect on the adoption of improved varieties but a negative effect on the extent to which the improved varieties of wheat were used in the Robe and Digelu-Tijo districts of the Arsi Zone. Women are usually deprived of access to external inputs and information [13], which decreases their likelihood of growing improved varieties. The adoption of new improved varieties was positively and significantly affected by the farmer's level of education. Farmers with higher level of literacy were more likely to adopt improved cultivars due to increased access to information, while farmers with lower levels of literacy were likely to be more averse to new technologies. Similarly, the education level of the household head was found to positively and significantly affect the adoption of improved varieties as reported by different researchers $[6,10,16,37]$. However, in another study no association was found between the farmer's level of education and adoption of improved varieties [46]. The main source of agricultural information for the majority of the sample households (65\%) was found to be agricultural extension officers. However, its effect on adoption of new improved varieties was significantly negative, corroborating the result found by Beshir and Wegary [6], who reported that visits by extension officers were negatively associated with the adoption of hybrid maize in the drought-prone central rift valley of Ethiopia. This implies that extension services were in favour of the previous traditional varieties that had already been cultivated by the farmers, which is a surprising outcome. On the other hand, the provision of extension services has been associated with technology adoption, and infrastructure and market access $[6,12,16]$.

Variety-specific traits, such as early maturity, plant height, adaptation and baking quality, were the major contributing traits required for adoption of improved bread wheat varieties. Grain yield, the trait most preferred by farmers, showed a positive but non-significant effect on the adoption of new improved varieties. Early maturity and plant height had positive and significant effects on the adoption of new improved varieties. This indicates that an improvement in these attributes would enhance the adoption of new improved varieties and should increase the overall production and productivity of bread wheat in drought-prone areas. However, poor baking quality and environmental adaptation negatively and significantly affected the adoption of improved varieties, which indicates these attributes were present only in traditional varieties. Kotu et al. [24] also reported the negative effect of poor baking quality on the adoption of improved wheat varieties in Adaba and Dodola woredas of the Bale Highlands of Ethiopia.

\section{Farmers' perceptions of the primary constraints to bread wheat production}

Respondent farmers ranked drought (moisture stress) as the most important production constraint followed by disease (especially rust), the high cost of fertilizers and heat stress, showing that the farmers in the study areas face a myriad of challenges that often occur simultaneously. Drought stress is the leading challenge among smallholder farmers in dryland farming [2, 34]. In other study, fungal diseases, the high cost of fertilizers, shortage of improved seeds and high seed prices were reported among the major production constraints in rust-prone, high-potential agro-ecologies of Ethiopia [19]. Abakemal et al. [1] found that access to inputs and inadequate rainfall were the major production constraints for maize production in the Highlands of Ethiopia. Other studies conducted in the Bale Highlands and Chilalo Awraja identified the high price of improved seed as an impediment to adoption of improved cultivars [12]. Zeleke [47] reported that drought, flood, crop pest/disease and hailstorm were the major climate change-related risk factors that influenced farmers' choices of adaptation measures in the Arsi zone of the Oromia region.

\section{Conclusions}

Farmers expressed a wide range of variety-specific trait preferences. Grain yield, rust resistance, adaptation to drought and heat stresses and early maturity were the most farmer-preferred traits. Socio-demographic factors, such as gender, education level and access to extension service, influenced variety adoption by the farmers. Early maturity, plant height, baking quality and stress adaptation were the major varietal characteristics contributing towards adoption of new improved bread wheat varieties. Drought stress, disease (especially rust) and the high cost of fertilizers were among the major constraints of wheat production that were identified by the farmers. This study can serve as a guide for future wheat breeding programmes incorporating farmer-preferred traits, including stress adaptation (drought and heat tolerance). This will enhance adoption of newly developed improved varieties and for sustainable production and food security of smallholder farmers in drought-prone areas. Future wheat improvement and extension programmes of the National Agricultural Research System (NARS) should involve marginal wheat-growing environments to boost adoption of new varieties and the production potential of the crop. The results of the present study were based on farmers' perceptions on variety needs and requirements, which should be considered as a preliminary guide in breeding wheat for drought-affected areas in Ethiopia. Further studies are required to confirm the association of 


\section{the perceived attributes with physical and genetic profile of the wheat varieties.}

\author{
Abbreviations \\ ACCl: African Centre for Crop Improvement; DAs: Development agents; AGRA \\ : Alliance for a Green Revolution in Africa; BONAR: Bureau of Agriculture and \\ Natural Resources; NARS: National Agricultural Research System; PPB: Participa- \\ tory plant breeding; PRA: Participatory rural appraisal; SPSS: Statistical Package \\ for Social Sciences; SSA: Sub-Saharan Africa.
}

\section{Acknowledgements}

The authors are grateful to all districts Bureau of agriculture staff, development agents and farmers of the study areas who made this participatory rural appraisal study possible. They thank the Ethiopian Institute of Agricultural Research and Holetta Agriculture Research Center for providing leave of absence and research support.

\section{Authors' contributions}

The authors designed the study and wrote the manuscript. YS collected and analysed the data and drafted the manuscript. HS reviewed and edited the manuscript. IM reviewed the manuscript. ML edited the manuscript. All the authors read and approved the final manuscript.

\section{Funding}

The study was funded by Alliance for a Green Revolution in Africa (AGRA) through African Centre for Crop Improvement (ACCl).

\section{Availability of data and materials}

The datasets used and/or analysed during the current study are available from the corresponding author.

\section{Ethics approval and consent to participate}

Not applicable.

\section{Consent for publication}

The authors have consent to the publication of this work.

\section{Competing interests}

The authors declare that they have no competing interests.

\section{Author details}

${ }^{1}$ School of Agricultural, Earth and Environmental Sciences, African Centre for Crop Improvement, University of KwaZulu-Natal, P. Bag X01, Scottsville, Pietermaritzburg 3209, South Africa. ${ }^{2}$ Ethiopian Institute of Agricultural Research, Holetta Research Centre, P.O. Box 2003, Addis Ababa, Ethiopia.

Received: 28 January 2020 Accepted: 2 February 2021

Published online: 08 June 2021

\section{References}

1. Abakemal D, Hussein S, Derera J, Laing M. Farmers' perceptions of maize production systems and breeding priorities, and their implications for the adoption of new varieties in selected areas of the highland agro-ecology of Ethiopia. J Agric Sci. 2013;5(11):159-72.

2. Adhikari U, Nejadhashemi AP, Woznicki SA. Climate change and eastern Africa: a review of impact on major crops. Food Energy Secur. 2015;4(2):110-32.

3. Asante MD, Asante BO, Acheampong GK, Wiredu AN, Offei SK, Gracen V, Adu Dapaah H, Danquah EY. Grain quality and determinants of farmers' preference for rice varietal traits in three districts of Ghana: Implications for research and policy. J Dev Agric Econ. 2013;5(7):284-94.

4. Asfaw S, Shiferaw B, Simtowe F, Lipper L. Impact of modern agricultural technologies on smallholder welfare: evidence from Tanzania and Ethiopia. Food Policy. 2012;37:283-95.

5. Asrat S, Yesuf M, Carlsson F, Wale E. Farmers' preferences for crop variety traits: Lessons for on-farm adoption. EfD Discussion Paper 09-15,
Environment for the future initiative and resources for the future, Washington DC. 2009.

6. Beshir B, Wegary D. Determinants of smallholder farmers' hybrid maize adoption in the drought prone central rift valley of Ethiopia. Afr J Agric Res. 2014;9(17):1334-43.

7. Bishaw Z, Struik PC, van Gastel AJG. Wheat seed system in Ethiopia: farmers'varietal perception, seed sources and seed management. J New Seed. 2010;11(4):281-327.

8. Ceccarelli S, Guimarães EP, Weltzien E. Plant breeding and farmer participation. Rome: Food and Agriculture Organization of the United Nations; 2009

9. Ceccarelli S, Grando S, Baum M. Participatory plant breeding in waterlimited environments. Exp Agric. 2007:43:411-35.

10. Chilot $Y$, Atnafe $Y$, AwHassan A. A multivariate analysis of factors affecting adoption of improved varieties of multiple crops: A case study from Ethiopian highlands. Ethiop J Agric Sci. 2015;25(2):29-45.

11. Central Statistical Agency (CSA). Area and Production of Crops in the Main Season. Statistical Bulletin, Central Statistical Agency (CSA), Addis Ababa, Ethiopia. 2016.

12. Doss $\mathrm{C}$, Mwangi W, Verkuijl $\mathrm{H}$, Groote $\mathrm{H}$. Adoption of maize and wheat technologies in eastern Africa: a synthesis of the findings of 22 case studies. CIMMYT economics working paper 03-01. Mexico, D.F.: CIMMYT. 2003.

13. Doss CR. Designing agricultural technology for African women farmers: lessons from 25 years of experience. World Dev. 2001;29(12):2075-92.

14. Drabo I, Zangre RG, Danquah EY, Ofori K, Witcombe JR, Hash CT. Identifying farmers' preferences and constraints to pearl millet production in the Sahel and North-Sudan zones of Burkina Faso. Expl Agric. 2018. https://doi.org/10.1017/S0014479718000352.

15. FAO. 2019. FAOSTAT. FAO, Rome. www.fao.org. Accessed 21 June 2019.

16. Gebresilassie L, Bekele A. Factors determining allocation of land for improved wheat variety by smallholder farmers of Northern Ethiopia. J Dev Agric Econ. 2015;7(3):105-12.

17. Gebreselassie S, Mekbib G, Matthias K. The wheat sector in Ethiopia: Current status and key challenges for future value chain development. Working paper 160. Centre for Development Research, University of Bonn. 2017.

18. Halewood M, Deupmann P, Sthapit B, Vernooy R, Ceccarelli S. Participatory plant breeding to promote farmers' rights. Rome: Bioversity International; 2007.

19. Hei N, Shimelis HA, Laing M. Appraisal of farmers' wheat production constraints and breeding priorities in rust prone agro-ecologies of Ethiopia. Afr J Agric Res. 2017;12(12):944-52.

20. Husmann C. Transaction costs on the Ethiopian formal seed market and implications for the private sector. Unpublished research report presented at the 11 th international conference on the Ethiopian economy. Addis Ababa, Ethiopia. 2014.

21. Joshi G, Bauer S. Farmers' choice of the modern rice varieties in the rainfed ecosystem of Nepal. J Agr Rural Dev Trop. 2006;107(2):129-38.

22. Kalinda T, Tembo G, Kuntashula E. Adoption of improved maize seed varieties in Southern Zambia. Asian J Agric Sci. 2014;6(1):33-9.

23. Kebede D, Ketema M, Dechassa N, Hundessa F. Determinants of adoption of wheat production technology package by smallholder farmers: evidences from Eastern Ethiopia. Turk J Agric For. 2017;5(3):267-74.

24. Kotu BH, Verkuijl H, Mwangi W, Tanner D. Adoption of Improved Wheat Technologies in Adaba and Dodola woredas of the Bale Highlands, Ethiopia. Mexico, Addis Ababa: CIMMYT, EARO; 2000.

25. Li J, Edith T, Buerenc L, Huang K, Qin L, Song Y. The potential of participatory hybrid breeding. Int J Agr Sustain. 2013;11(3):234-51.

26. Minot N, Warner J, Lemma S, Kassa L, Gashaw A, Rashid S. The wheat supply chain in Ethiopia: Patterns, trends, and policy options. Washington: International Food Policy Research Institute (IFPRI); 2015.

27. Morris ML, Bellon MR. Participatory plant breeding research: opportunities and challenges for the international crop improvement system. Euphytica. 2004;136:21-35.

28. Mulugeta T, Hundie B. Impacts of adoption of improved wheat technologies on households' food consumption in South-eastern Ethiopia. International association of agricultural economists (IAAE) triennial conference, 18-24 August, Foz do Iguaçu, Brazil. 2012. 
29. Piguet F. Assessment field trip to Arsi Zone (Oromiya Region). Field Assessment Mission, 7-10 April and 15-17 April, UN-EUE, Addis Ababa. 2003.

30. Rashid S, Lemma S. Public wheat imports since 2008: The rationales and cost effectiveness. Washington: Research for Ethiopia's Agriculture Policy (REAP), International Food Policy Research Institute; 2014.

31. Shiferaw B, Kassie M, Jaleta M, Yirga C. Adoption of improved wheat and impacts on household food security in Ethiopia. Food Policy. 2014:44:272-84.

32. Solomon T, Tessema A, Bekele A. Adoption of improved wheat varieties in Robe and Digelu Tijo Districts of Arsi Zone in Oromia region, Ethiopia: a double-hurdle approach. Afr J Agric Res. 2014;9(51):3692-703.

33. Statistical Product and Service Solutions (SPSS). SPSS for Windows Release 24.0. SPSS Inc. 1989-2016. IBM Company. 2016.

34. Tadesse W, Bishaw Z, Assefa S. Wheat production and breeding in Sub-Saharan Africa: challenges and opportunities in the face of climate change. Int J Clim Chang Str. 2019;11(5):696-715.

35. Tadesse W, Solh M, Braun HJ, Oweis T, Baum M. Approaches and strategies for sustainable wheat production. Beirut: International Centre for Agricultural Research in the Dry Areas (ICARDA); 2016.

36. Temesgen T, Hassan RM, Ringler C. Measuring Ethiopian farmers'vulnerability to climate change across regional states. International Food Policy Institute. 2008.

37. Thomson K, Gelson T, Elias K. Adoption of improved maize seed varieties in Southern Zambia. Asian J Agric Sci. 2014;6(1):33-9.

38. Thro AM, Spillane C. Biotechnology-assisted participatory plant breeding: complement or contradiction? - working document number 4- April 2000- CGIAR. 2000.

39. Tongoona P, Danqah A, Danqah EY. Understanding clients' needs. In: Persley GJ, Anthony MV, editors. The business of plant breeding: market-led approaches to new variety design in Africa. London: CABI; 2017. p. 63-84.

40. Tura M, Aredo D, Tsegaye W, Rovere R, Tesfahum G, Mwangi W, Mwanbu $\mathrm{G}$. Adoption and continued use of improved maize seed. Case study of central Ethiopia. Afr J Agric Res. 2010;5(17):2350-8.
41. Vernooy R, Stanley B. Breeding better barley-together: a new way to work with farmers in dry areas: seeds that give. Ottawa: Participatory Plant Breeding Case Study Series International Development Research Centre, IDRC; 2003.

42. Warner J, Tim S, Leulsegged K. Woreda-level crop production rankings in Ethiopia: a pooled data approach. Addis Ababa: International Food Policy Research Institute (IFPRI); 2015.

43. Witcombe JR, Joshi A, Goyal SN. Participatory plant breeding in maize: a case study from Gujarat. India Euphytica. 2003;130:413-22.

44. Witcombe JR, Joshi KD, Gyawali S, Musa AM, Johansen C, Virk DS, Sthapit BR. Participatory plant breeding is better described as highly clientoriented plant breeding. I. Four indicators of client-orientation in plant breeding. Exp Agric. 2005;41:299-319.

45. Wondale L, Molla D, Tilahun D. Logit analysis of factors affecting adoption of improved bread wheat (Triticum aestivum L.) variety: The case of Yilmana Densa District, West Gojam Ethiopia. J Agric Ext Rural Dev. 2016;8(12):258-68.

46. Zegeye T, Taye G, Tanner D, Verkuij H, Agidie A, Mwangi W. Adoption of improved bread wheat varieties and inorganic fertilizer by small-scale farmers in Yelmana Densa and Farta districts of North-western Ethiopia. Mexico, Addis Ababa: CIMMYT, EARO; 2001.

47. Zeleke Z. Adaptation strategies of small holder farmers to climate change on wheat production in selected districts of Arsi Zone, Oromia Regional State, Ethiopia. Hawassa: M.A. Thesis Hawassa University; 2017.

\section{Publisher's Note}

Springer Nature remains neutral with regard to jurisdictional claims in published maps and institutional affiliations.
Ready to submit your research? Choose BMC and benefit from:

- fast, convenient online submission

- thorough peer review by experienced researchers in your field

- rapid publication on acceptance

- support for research data, including large and complex data types

- gold Open Access which fosters wider collaboration and increased citations

- maximum visibility for your research: over 100M website views per year

At BMC, research is always in progress.

Learn more biomedcentral.com/submissions 